\title{
Formation and development of national system of financial- credit maintenance of agrarian manufacture
}

\section{Voitiuk A.}

National academy of agrarian sciences of Ukraine, Mykhailo Omelianovych-Pavlenko Str., 9, Kyiv, 01010, Ukraine; e-mail: vdv-tsim@ukr.net

The purpose. To raise efficiency of agroindustrial sector of economy of Ukraine due to development of the concept of National system of financial-credit maintenance of agrarian manufacture in view of experience of the developed countries, as well as to determine opportunities of its application in domestic practice. Methods. Technique of researches was based on the system approach and dialectic method of studying financial phenomena and processes in view of monographic method, methods of synthesis and analysis. Results. Means, receptions and methods of system of financial-credit maintenance of agrarian manufacture allowing involving local financial mechanisms effectively are considered. Necessity is substantiated of formation and development of this system for a context of warranting high level of adaptability to changes in external economic environment and internal financial and economic condition, and also stable economic development of agrarian manufacture. Conclusions. Formation and development in Ukraine of National system of financial-credit maintenance of agrarian manufacture is the only comprehensible method of increase of efficiency of agroindustrial sector of economy.

Key words: agrarian manufacture, financial system, credit system, analysis, bank, crediting, bank technologies, agriculture.

https://doi.org/10.31073/agrovisnyk201806-12

The agro-industrial sector of Ukraine economy today is a leader among other industries as for in attracting foreign currency from export of agricultural products, and in general the overall GDP of the country. So in 2016, the foreign exchange earnings from agricultural exports totalled 11 billion US dollars, and share in total GDP of Ukraine $-12 \%$. It should be noted that crop production from year to year is 60-65 million tons [1].

At the same time, there is substantial potential for increasing production from enterprises of the agro industrial complex. For example, the quantity of machinery on the country's fields from technologically necessary need not exceed $75 \%$. The specified leads to a significant loss of biological yield. In 2016 , they amounted to 1.2 billion US dollars (tranche from the IMF this year amounted to 1 billion US dollars).

The above demonstrates the need for significant financial support to the agricultural sector. So on its technical re-equipment need up to 300 billion UAH. [2]. The only effective way of solving this problem is the formation and development the National system of financial and credit support of agricultural production in Ukraine.

Financial and credit support of agricultural production $[3,4,5]$ is a combination of financial and credit relations in the process of search the attraction and efficient use of financial resources of economic subjects in agricultural production. The main strategic objectives of the development financial and credit provision of agricultural production are: the establishment of financial-credit relations of agricultural producers to meet the needs of agricultural production in credit resources, formation of effective system of insurance of risks of agricultural enterprises, improving the system of state financial support for the development of agricultural production.

The purpose of research.Increase the efficiency of the agro-industrial sector of the Ukrainian economy by developing a concept of the system of financial and credit provision of agricultural production, taking into account the experience of the advanced countries of the world, determining the possibilities of its application in domestic practice. 
The research methods. The work material is based on organizational and economic principles of formation and development of national model the financial and credit support of agricultural enterprises. Research methodology was based on a systematic approach and the dialectical method of financial disclosure and processes in consideration of the monographic method, methods of synthesis and analysis.

The results of the research. The development of the national system of financial and credit support of agricultural production illustrates the ability in confronting internal and external challenges and ensure stable development of agricultural production.

On the basis of analysis and generalization of the existing theoretical framework, gave the opportunity to argue that the concept of "national system of financial and credit support of agricultural production" on the basis of the functional approach, which provides for the disclosure of financial and credit system from the position, which is a complex set of interrelated and interacting credit and financial institutions, including government and commercial banking institutions, nonbank credit institutions, financial instruments, mechanisms and procedures which aim to ensure the financial activities of the agricultural producer, which creates conditions to ensure the process of expanded reproduction.

To create adequate National financial and credit system of servicethe agricultural production requires the search for forms of interaction, areas that meet global requirements and preserve crucial distinctive and effective that meets the national interests of financial institutions and instruments.

Improving the efficiency the system of financial and credit support of agricultural production in the conditions of globalization is inextricably linked with the systemic regulation of key areas of the public financial policy and the efficiency of its functioning depends on the goals and objectives arising from the long-term financial strategy of the country.

Specified greatly depends on the use of modern scientific and methodological substantiation of the approaches to the development of the financial system in the context of globalization, given the fact that the "factor" of globalization is becoming more significant in the adoption of practical solutions for the development of the national system of financial and credit support of agricultural production.

The scientific rationale of the vector of formation the financial and credit system has been crushed in the evolutionary movement of scientific search from conceptual and methodological (the nature of the financial and credit architecture) to systemic-functional (research features) and functional-methodological levels (methodological tools for analysis of strategies).

In the process of developing theoretical and methodological approaches to the decomposing the system of financial and credit support of agricultural production must be consider functionally meaningful segmentation, which will allow to take into account the needs, interests and financial opportunities of agricultural producers.

At the initial stage, the allocation of the main segments of the financial and credit system, the relationship which provides effective mechanisms for financial regulation, planning and control, which ensure the implementation of its functionality. Further stages offer in-depth structuring of key segments, which include a multi-faceted set of tools, levers, incentives, procedures and rules aimed at solving individual problems of financial regulation.

Further stages offer in-depth structuring of key segments, which include a multi-faceted complex of tools, levers, incentives, procedures and rules aimed at solving individual problems of financial regulation.

The National system of financial and credit support of agricultural production includes main segments:

$>$ financial system:

* structuralunitsbudgets:

- statebudget;

- local budgets;

- the budgets of subjects of the agrarian producers;

* theinsurancesegment

* the taxsegment 


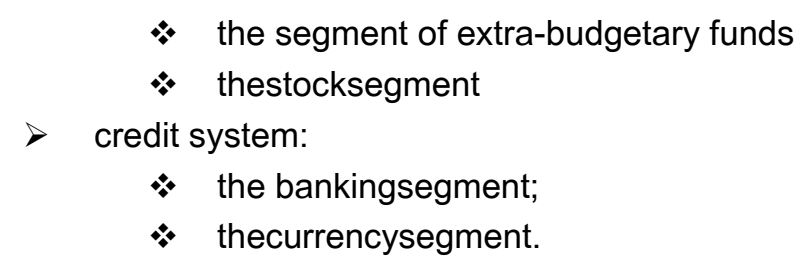

This segmentation the National system of financial and credit support of agricultural production does not violate her fundamental integrity, take into account the interrelation and interpenetration of functions in the implementation of specific solutions for the development of this system.

The additions to the financial structure of the National system of financial and credit support to the agricultural production its institutional and functional structuring, which includes the following components:

$>$ institutional infrastructure (public financial bodies, banking institutions, insurance companies, stock exchanges, microfinance institutions, etc.);

$>$ financial instruments (budget, cash, securities, certificates, agricultural receipts, letters of credit, promissory notes, etc.);

$>$ legal (legislative and regulatory framework, rules of thumb, etc.).

The structural architectonics of the National financial and credit system for serve farmers acquires special significance, as it affects institutional and infrastructural tools in different ways, differentiation requires tough decisions and a global assessment in the context of ensuring the financial security of agricultural producers.

The banking system $[6,7]$ is one of the most important segments of the financial system, which directly affects the development of innovation processes, which consist in the introduction of new banking products and innovative approach with a combination of existing techniques, means, methods and tools. That allows you to simulate a variety of innovative banking products for bank competitive advantages in the segments of business entities, in particular in the agricultural sector.

One of the modern problems in the banking sector is the increase of unprofitable banks. On 01.01.2016 them was a 46 - almost a quarter of the entire banking system. While the losses of banking institutions amounted to 66.6 billion UAH (over the same period in 2014 they amounted to 52,96 billion $\mathrm{UAH}$ ). Over half of the banking institutions were at risk of elimination, as only 43 banks have capital of more than UAH 300 million, and the other in failing to supplement their charter capital will be eliminated [8].

Especially negative is the situation with loans to agricultural enterprises whose debt is growing every year. According to the National Bank of Ukraine, the volume of new loans to agriculture amounted for 10 months of 20164694 million, and arrears - 6050 million. These negative trends are of different nature, in particular, bank losses linked to the weakness of regulation of their reserve funds in NBU, the debt of agricultural enterprises linked to the inefficiency of work of management of the banks and the customers [9].

This situation increases the potential for systemic risk, significantly reduces the efficiency of the banking system, its ability to provide a solution of strategic problems of the economy.

In the conditions of transformation of the financial architecture at the level of national financial and credit system, the banking system is a key element in ensuring the stability of the financial system of agricultural production. Organizational-economic principles of formation and development of modern national models of financial and credit support of agricultural production are:

- provision of efficient redistribution of capital within the banking system and increase its capitalization;

- development of standards for banking risk management, taking into account the cyclical economic development;

- the reduction in net external debt of banks and recapitalization of the banking sector;

- the increase volume in domestic sources of savings;

- the consolidation of the banking sector;

- creation of favourable economic growth mode of crediting of agrarian sector. 
The modern imperative of development of the credit subsystem is the activation of innovation processes, which consist in the introduction of new banking products and the application of innovative approach to customer service with a combination of existing techniques, means, methods, and tools for implementation of modern banking technologies. Such a vision allows to simulate various innovative banking products for a bank's competitive advantages in various segments of the national economy, including in the agricultural sector.

The newest stage of competition of banking services is characterized by the increasing role of innovative technologies in banks, the formation of new horizons of the market for servicing of subjects of agrarian producers, and also increase multidirectional services in the banking market.

The innovation process covers various activities of banks, in particular the introduction of innovative financial technologies that would facilitate the updating of existing and creation of new financial products, the restructuring of banks, the strengthening of internal controls, implementation of innovation management. The conception of innovative technologies of banks based on two complementary approaches: kaizen approach that seeks to combine stage improvement of business, improve qualification of employees: managers level and staff level and approach focused on "innovative development".

One of the most innovative banking products of today are remote banking services, with the use of communication and Internet technologies, by means of it banks can explore new areas without opening new branches, as well as bank cards, mobile banking, dealing, wireless technologies and so on.

The development of innovative lending products for agricultural production requires banking institutions in the transition to a customer centric approach, in particular, they must move away from being sellers of services and become consultants for their clients- agriculturist, to create favorable conditions for the development of their business by encouraging credit products for the modernization of agricultural production, introduction of new technologies to produce competitive agricultural products.

Implementation development of the National system of financial and credit support includes the following priorities in the funding and support of agricultural production [10].

1. Legislative definition of the status of the national financial and credit system of agricultural producers.

2. The development and adoption of normative-legal base of functioning of the national financial and credit system of agricultural producers.

3.

Theformationanddevelopmentofthenationalfinancialsystemofserviceofagriculturalproducersonthebasisofes tablishmentthespecializedState-ownedagriculturalBankas

principalagentofthestateinthesphereofprovidingcreditresourcestoagriculturalproducers,

performscreditandenvironmental-structuralfunctions. Such a system should include a set of credit and financial institutions (banking institutions, non-banking financial intermediation institutions, including credit cooperatives), as well as financial infrastructure organizations, which provide financial support to the process of reproduction in agriculture.

4. Inclusion in the national financial and credit system of service of agricultural producers of all banks , in the loan portfolios of which the share of customers of business entities in agriculture exceeds $25 \%$.

5. To oblige the State agricultural Bank to unite efforts of all participants in the national financial system of service of agricultural producers from the development of uniform standards of credit policy, achieving acceptable parameters of efficiency and reliability, that allow to provide real support for implementation states programs the development of agrarian economy.

6. To recommend to the National Bank of Ukraine and the Ministry of Finance of Ukraine to introduce in respect of participants in the national financial and credit system of agricultural producers of legal, regulatory, supervisory and tax regulations, taking into account the specificity of their interaction with the agro-industrial complex.

7. The development and activation of land mortgage with long-term loans at reasonable (perhaps subsidized) interest rates. 
8. Formation of the market and technology the introduction of land mortgage-backed securities, as well as to provide refinancing of land mortgage loans.

9. The improve efficiency of participation members of the national financial and credit system of agricultural producers in the implementation of programs, their financial rehabilitation through concerted and joint decisions of their debt problems.

10. To provide institutional, legal, capital and resource support to the creation and development of cooperative banks with the participation of small and middle agricultural producers.

11. State financial support for the development of credit cooperatives as the main source of microcredit, personal rural households and small businesses in rural areas.

\section{Conclusions}

InthisarticleshownthatonlyacceptablewayofincreasingefficiencyoftheagroindustrialsectorofeconomyisformationanddevelopmenttheNationalsystemoffinancialandcreditsupportofagri culturalproductioninUkraine.

This system should include a synthesis of the basic segments: of the financial system and credit system. The role of banking system, which is affecting the development of innovative processes, offers the opportunity to model innovative banking products in the agricultural sphere.

On the basis of the organizational-economic principles given the developed model of financial and credit support of agricultural production.

Here proposed funding priorities and support the agricultural sector, based on the need of realization of the developed concept of National system of financial and credit support of agricultural production Ukraine.

\section{Bibliography}

1. Zhuk I.M. (Ed). (2017). Natsionalni rakhunky. Silske, lisove ta rybne hospodarstvo. Myslyvstvo. [National Accounts. Agriculture, forestry and fisheries. Hunting ]. Statystychnyi shchorichnyk Ukrainy za 2016 r. Derzhavna sluzhba statystyky Ukrainy. Kyiv. 575 p. [in Ukrainian].

2. Zakharchuk O. (2015). Problemy modernizatsii osnovnoho kapitalu ahrarnoho sektoru ekonomiky. Innovatsiine zabezpechennia vyrobnytstva orhanichnoi produktsii ta biopalyva v APK» v ramkakh roboty XXVII Mizhnarodnoi ahropromyslovoi vystavky «AHRO 2015». [Problems of modernization of fixed capital of the agrarian sector of the economy. Innovative support for the production of organic products and biofuels in the agroindustrial complex "within the framework of the XXVII International Agro-Industrial Exhibition" AGRO 2015 "]. Zbirnyk tez dopovidei III mizhnarodnoi naukovoi konferentsii 05-06 chervnia. Kyiv. P. 58 - 62. [in Ukrainian].

3. Hudz O.le. (2012). Modernizatsiia bankivskoi kredytnoi polityky pry obsluhovuvanni ahroformuvan. Visnyk Kharkivskoho natsionalnoho tekhnichnoho universytetutu silskoho hospodarstva: [Modernization of bank credit policy while servicing agroformations]. Ekonomichni nauky. Vyp. 126. Kharkiv: KhNTUSH. P. 10 - 18. [in Ukrainian].

4. Liubar O.O. (2010). Osoblyvosti formuvannia kredytnoi polityky bankiv pry obsluhovuvanni subiektiv ahrarnoi sfery. [Features of forming of credit policy of banks at servicing of subjects of agrarian sphere]. Zbirnyk naukovykh prats Vinnytskyi natsionalnyi ahrarnyi universytet. Seriia «Ekonomichni nauky». T. 2. Vypusk. 5. P. $224-230$. [in Ukrainian].

5. Stetsiuk P.A. (2011). Problemy finansovoho zabezpechennia silskohospodarskykh pidpryiemstv. [Problems of financial support of agricultural enterprises]. Oblik i finansy APK. № 4. P. 134-137. [in Ukrainian].

6. Vdovenko L.O. (2015). Mekhanizm bankivskoho kredytuvannia v systemi finansovoho zabezpechennia pidpryiemnytskoi diialnosti $v$ ahrarnii sferi [The mechanism of bank lending in the system of financial provision of entrepreneurial activity in the agrarian sector]. dysertatsiia ... doktora ekonomichnykh nauk: spetsialnist 08.00.08 - Hroshi, finansy i kredyt: zakhyst 27.05.2015. 534 p. [in Ukrainian]. 
7. Onysko S.M., Sodoma R.I. (2015). Kredytni vidnosyny ahrarnykh pidpryiemstv z bankamy. [Credit relations of agrarian enterprises with banks]. Lviv: Liha-Pres,. 196 p. [in Ukrainian].

8. Finansovyi rezultat diialnosti bankiv Ukrainy za 2015 r. [The financial result of the Ukrainian banks in 2015]. Biuleten Natsionalnoho banku Ukrainy. 2016. № 2(275). 223 p. [in Ukrainian].

9. Voitiuk A.V. (2017). Instytutsionalizatsiia rynku bankivskykh posluh $v$ umovakh makroekonomichnoi nestabilnosti. [Institutionalization of the market of banking services in the conditions of macroeconomic instability]. Zbirnyk tez dopovidei XIII Mizhnarodnoi naukovoi konferentsii "Ratsionalne vykorystannia enerhii v tekhnitsi. TechEnergy 2017» (17 - 19 travnia 2017 roku). NUBiP Ukrainy. Kyiv,. 198 p. [in Ukrainian].

10. Stecyuk P.A., Navrockij S.A., Vojtyuk A.V. (Parmakli D.M. Ed). (2017). Nacionalnaya sistema finansovokreditnogo obespecheniya agrarnogo proizvodstva. Sovremennye dostizheniya nauki i puti innovacionnogo voshozhdeniya ekonomiki regiona strany [National system of financial and credit provision of agricultural production. Modern achievements of science and ways of innovative ascent of the economy of the region of the country]. Materialy mezhdunarodnoj nauchno-prakticheskoj konferencii (Komrat, 18 maya 2017 g.). Komrat: Komratskij gosudarstvennyj universitet. C. $346-354$. [in Russian]. 